\title{
Natalia Lemann
}

Uniwersytet Łódzki

\section{Miejsca (nie)PODobne - toponimia w historiach alternatywnych}

Historie alternatywne to jeden z najpopularniejszych gatunków prozy fikcjonalnej, spekulatywnej, rozgrywający się w świecie, w którym wydarzenia historyczne miały przebieg odmienny niż ten znany ze świata rzeczywistego. W powieściach tych autorzy twórczo rozwijają spekulacje probabilistyczne w historii, odpowiadając na pytanie ,co by było, gdyby”. W tym głęboko osadzonym w refleksji historycznej gatunku z niezwykłą mocą wybrzmiewa teza - wielokrotnie formułowana m.in. przez Cultural Studies, nowy historyzm, antropologię literatury i Subaltern Studies - iż literatura zawsze jest uwikłana w politykę. Przekonania polityczne i światopoglądowe autora przenikają do świata przedstawionego również w sposób nie do końca uświadamiany przez twórców, „infekując” niejako powieściowe światy ideologicznie [Greenblatt 2006; Gallgher, Greenblatt 2000; Veeser 1994, Foucault 1993, 2002; Franczak 2012; Jameson 1981; Ranciére 2008; Said 2005, 2009]. Zatem również odejście od utartego, powszechnie znanego przebiegu dziejów nie może zostać uznane za zabieg niewinny światopoglądowo i aksjologicznie. Wymyślanie alternatywnych scenariuszy historii jest zazwyczaj objawem niezadowolenia autora z przeszłości w jej dokonanym, powszechnie znanym kształcie. Kształt historii alternatywnej jest zatem wypadkową poglądów polityczno-historycznych autora i jego stosunku zarówno do historii, jak i teraźniejszości. W efekcie często mamy do czynienia $\mathrm{z}$ resentymentowym i życzeniowym stosunkiem do świata i przeszłości [por. Demandt 1999; Ferguson 1997; Hellekson 2001; Lemann 2011a, 2011b, 2012b, 2012c].

Niezbywalnym elementem tworzenia historii alternatywnych jest wskazanie POD (point of divergence) i rozwinięcie jego konsekwencji. POD to punkt, w którym historia świata kreowanego potoczyła się inaczej niż w świecie aktualnym. Literacka historia alternatywna jest niejako konsekwencją wyboru przez pisarza owego punktu zróżnicowania wydarzeń historycznych. W celu zapewnienia komunikatywności dokonanej kreacji, umożliwienia wpisanej w scenariusz lekturowy czytelnika modelowego konkretyzacji czytelniczej, autor historii alternatywnej przez cały czas odwołuje się do świata aktualnego, do znanych czytelnikowi wydarzeń historycznych. Tradycyjnie, choć nie do końca słusznie, historie 
alternatywne lokowane są w obrębie literatury fantastycznej [por. Lemann 2011a: 341], stąd naczelną zasadą kreacji świata przedstawionego jest relacyjność i intertekstualność, polegająca na bezustannym konfrontowaniu świata przedstawionego z aktualnym, nieznanego z oswojonym i w efekcie oswajanie nieznanego. Podstawowy problem literatury fantastycznej polega przecież na tym, by w taki sposób wykreować wtórny, nieprzyległy wobec empirycznego świat, by czytelnik był w stanie w nim się „zadomowić”. Problemem staje się tu niejako „przepisanie” znanego autorowi świata aktualnego na język i kod percepcyjny czytelnika, tak by umożliwić immersję w proponowany świat, a jednocześnie skłonić do odbioru zgodnego z fabułą. M.-L. Ryan twierdzi, że ,by immersja mogła zaistnieć, tekst musi zaoferować przestrzeń, w którą można się zanurzyć, [...] a przestrzeń ta nie jest oceanem, ale tekstowym światem." [Ryan 2001: 89]. Istotna jest tu modalna rama kultury wprowadzona $\mathrm{w}$ obręb wykreowanego uniwersum, pozwalająca m.in. na zwiększenie bądź zmniejszenie dystansu czytelnika do proponowanego świata [Stoff 1994, Lemann 2002: 139-140]. Wydaje się, że jednym z takich drogowskazów może być właśnie toponimia, jako czynnik służący konstrukcji apelatywnej struktury tekstu [Iser 2006] oraz nakłonieniu odbiorcy do lektury relacyjnej, intertekstualnej, świadomej spiętrzonej gry pomiędzy tym, co historyczne - tym, co faktycznie wydarzyło się w toku znanych nam dziejów - a tym co mogłoby być, czyli przeszłością wykreowaną w świecie przedstawionym. Twórca historii alternatywnych zaprasza czytelnika do podjęcia gry polegającej na rozpoznaniu zmienionego scenariusza historii, identyfikacji pierwowzoru i zrozumienia dokonanych modyfikacji w obrębie przywołanych postaci i wydarzeń. Najważniejszym wyzwaniem dla czytelnika modelowego jest jednakże deskrypcja wyższego poziomu, polegająca na odczytaniu ironicznie potraktowanych reguł historii jako nauki i jej filozofii, a także satyrycznego komentarza do świata aktualnego.

Pisarze, chcąc uwiarygodnić dokonaną kreację, sięgają po liczne fikcyjne bądź zmienione makro- i mikrotoponimy, ojkonimy, etnonimy, czy nawet chrematonimy, wiążąc je $\mathrm{z}$ alternatywnie budowanym scenariuszem przebiegu wydarzeń historycznych. Interesujące wydaje się więc zbadanie kreacji toponimicznych w historiach alternatywnych zgodnie z następującymi zagadnieniami: wykorzystanie wiadomości historycznych przez autora i wtórnie przez czytelnika w celu przyswojenia i zrozumienia dokonanej kreacji; alternatywizowanie dyskursu historycznego poprzez toponimię, kulturowe uwarunkowania toponimii, problemy odbioru (kompetencje nadawcze i odbiorcze). Napięcie pomiędzy rozpoznawalnością a obcością występującej w tym gatunku toponimii zasygnalizowane jest poprzez zaproponowany w tytule niniejszego artykułu kalambur ,miejsca (nie)PODobne", wykorzystujący prymarną dla historii alternatywnych kategorię POD, point of divergence. Nazwy miejscowe są w tym gatunku - tak samo jak historia - (nie)PODobne ${ }^{1}$. Jako kontekst komparatystyczny przywołać można genialny

\footnotetext{
${ }^{1}$ Kalambur „historia niePODobna” zaproponowałam m.in. w: N. Lemann [2011b, 2012d].
} 
kalambur T. Morusa, 'utopia', który współcześnie oznacza nazwę gatunku literackiego zdecydowanie bardziej, niż wykreowaną przez wyobraźnię biskupa idealną wyspę. Utopia, to równocześnie 'eu-topos', czyli miejsce dobre, jak i 'ou-topos' czyli miejsce nieistniejące. Owa płynność semantyczna terminu jest niemożliwa do usunięcia. Tak też i w historiach alternatywnych zarówno same dzieje, jak i toponimia są i nie są podobne do znanych ze świata aktualnego.

Ponieważ metodologicznie niniejszy artykuł oparty jest głównie na epistemologii i metodologii historii, antropologii kulturowej i literackiej, stąd też materiał badawczy wywiedziony $\mathrm{z}$ analizowanych powieści prezentowany będzie $\mathrm{w}$ granicach konkretnego materiału literackiego, a dopiero wtórnie zostaną wyprowadzone ogólne reguły rządzące toponomastyką literacką w historiach alternatywnych. Obecna $\mathrm{w}$ powieści toponomastyka nie jest tworem samodzielnym, a jednym z elementów kreujących świat przedstawiony i jej analiza musi zostać przeprowadzona w obrębie macierzystego kontekstu.

\section{Nominare et impera! - Brunatna rapsodia Otto Basila}

Niewątpliwie jednym z najczęściej powtarzających się literackich scenariuszy kontrfaktycznych jest zwycięstwo państw Osi w II wojnie światowej [por. Rosenfeld 2005]. Powieści takie jak Brunatna rapsodia Otto Basila [Basil 1993, pierwodruk: 1966, Wenn das der führer wüsste], Vaterland Roberta Harrisa [Harris 1997, pierwodruk: 1992] czy Pan z wysokiego zamku Philipa K. Dicka [Dick 1991, pierwodruk:1962] dostarczają wyjątkowo rozbudowanej toponimii. Oto bowiem Rzesza Niemiecka, wygrywając wojnę, wasalizuje większość świata, na nowo kreśląc mapy. Historia należy do zwycięzców, a ci chcą odpowiednio uzasadnić i podkreślić swą hegemonię polityczną. Przemianowują więc całe państwa, miasta czy regiony, podkreślając tym samym swą potęgę i kreując nowy świat. Toponimia jako narzędzie hegemonii, subalteryzujące poddanych nie jest pomysłem stricte literackim. Wystarczy bowiem przypomnieć, jak dużą wagę do nadawania nowych nazw skolonizowanym, podbitym państwom czy regionom przykładano w starożytnym Rzymie czy w cesarstwie Napoleona Bonaparte. Przykładowo Juliusz Cezar, podbijając region dzisiejszej Francji i Belgii, nazwał ją Galią, dzieląc na trzy części. Gallia est omnis divisa in partes tres. Tak brzmi pierwsze zdanie Pamiętników z wojny galijskiej Juliusza Cezara. Pierwszą zamieszkiwali Belgowie, drugą Akwitańczycy, trzecią Celtowie i dzieliła się, a raczej została podzielona, na Galię Przedalpejską i Zaalpejską, by następnie przez Oktawiana Augusta ulec dalszemu podziałowi na sześć części, z których tzw. Tres Galiaes (Galia Aquitania, Galia Belgica i Galia Lugdunensis) stały się własnością cesarską, a trzy następne - Galia Inferior, Galia Superior i Galia Narbonensis - były prowincjami rzymskimi. Divise et impera, a właściwie nominare et impera! Ze skuteczności tej polityki doskonale zdawano sobie sprawę we Francji w czasach 
Dyrektoriatu. Szwajcarię przemianowano na Republikę Helwecką (1798 r.), sięgając do łacińskiej nazwy jednej z prowincji rzymskich. Hitler odwoływał się do tych imperialnych przykładów, bo w jego filozofii politycznej tysiącletnia Rzesza Niemiecka miała być tworem wspanialszym i trwalszym od Imperium Romanum czy Pierwszego Cesarstwa Bonapartego.

W dystopijnej, katastroficznej czy wręcz apokaliptycznej powieści Otto Basila z 1966 r. Brunatna rapsodia, Hitler wygrał II wojnę światową. Bomba atomowa spadła zaś na Londyn, a nie na Hiroszimę, łamiąc tym samym opór aliantów. Imperium Germańskie obejmuje pół świata, a drugie pół podporządkowane jest Japonii. Słowianie są niewolnikami, Żydów eksterminowano. Nawet USA, zwane w tej powieści Stanami Zależnymi Ameryki Północnej (interwersja rozszerzająca etnonim) rządzone są przez Ku-Klux-Klan, który rozkazy otrzymuje z Berlina. Ironiczny wydźwięk ma nazwa powieściowej III Rzeszy. Ten ogromny twór polityczny zwany jest Światową Ariogermańską Wspólnotą Narodów [Basil 1993: 15], co niewątpliwie jest aksjologicznie wykrzywionym odpowiednikiem ONZ ze świata aktualnego. W różnych momentach akcji powieści, np. w sprawozdaniu z pogrzebu Adolfa Hitlera czy propagandowych audycjach radiowych, pojawiają się makro- i mikrotoponimy, głównie etnonimy, służące głównie kreacji historii alternatywnej. To właśnie dzięki nazwom państw opisywanego w powieści świata można zdekodować przebieg zwycięskiej dla Rzeszy wojny i tym samym nakreślić polityczną mapę świata. Nazwy takie jak Protektorat Osmański [Basil 1993: 13], Protektorat Rzeszy Hongkong [Basil 1993: 252], Protektorat Bałtycki [Basil 1993: 31], Protektorat Anglosaski [Basil 1993: 303] wskazują na fakt, że wymienione państwa jako protektoraty posiadają własne ustroje polityczne, lecz są uzależnione w swej polityce zagranicznej od Imperium. Wiedeń w świecie wykreowanym przez Basila stał się stolicą Marchii Wschodniej [Basil 1993: 14]. Basil, tworząc taką kreację toponimiczną, chciał podkreślić hegemoniczne zapędy zwycięskiej w jego świecie III Rzeszy. 'Marchia' oznaczała teren przygraniczny Imperium Karolińskiego, Posłużenie się terminem 'marchia' pozwoliło wskazać na odwoływanie się przez Hitlera do minionej hegemonii narodu niemieckiego, gdzie III Rzesza miała niejako być spadkobierczynią i kontynuatorką Świętego Cesarstwa Rzymskiego Narodu Niemieckiego. To zaś, że marchia, twór polityczny wywiedziony z historii społeczno-politycznej średniowiecza, zorganizowany był jako struktura feudalno-wojskowa, pozwala wysnuć wniosek, że świat wykreowany przez Basila osunął się w „mroki średniowiecza”. Jest to trafny wniosek, gdyż w Brunatnej rapsodii został opisany antyutopijny świat, w którym do łask powróciły przesądy, tortury, pradawne nordyckie rytuały.

W podobnym celu Basil aktywuje również zapomniane etnonimy, np. Waregowie. Co ciekawe, nie odbiega to tak daleko od prawdy historycznej. Hitler, jak wiadomo, był zainteresowany „magicznymi” artefaktami, wywiedzionymi z pradawnych kultów, m.in. nordyckich. Artefakty te, jak wierzył, mogłyby wzmocnić panowanie III Rzeszy. Bardzo interesująca jest również następująca kreacja 
toponomastyczna: Autonomiczne włości kozackie na Kubaniu, ze stolicą Mazepa (sic!). Nazwa fikcyjnej stolicy została utworzona od nazwiska Jana Mazepy herbu Kołodyn (1639-1709), który lawirując pomiędzy Rosją Piotra I a królami Polski, starał się wywalczyć autonomię dla Kozaków. W historiografii rosyjskiej Mazepa jest przedstawiany jako zdrajca Rusi i prawosławia, a powieściowe kozackie włości autonomiczne zostały wykrojone właśnie kosztem cesarstwa rosyjskiego. W Brunatnej rapsodii pokonany Związek Radziecki zwie się Ostland, czyli Ziemie Wschodnie. Toponimia służyła więc również upokorzeniu wroga, skoro zrezygnowano z jakiejkolwiek etnonimicznej kreacji wskazującej na państwowość dawnego ZSRR. Znana ze świata aktualnego Korea w powieści Basila nosi nazwę Mandżukuo. Pisarz posłużył się nazwą marionetkowego państewka utworzonego przez Japonię w Mandżurii w 1932 r. Dzięki takiej kreacji onomastycznej autor nie ma potrzeby wyjaśniania sposobu, w jaki Japonia zarządzała podległymi sobie terytoriami. Nawet czytelnik obeznany $\mathrm{z}$ historią w sposób podstawowy będzie w stanie zinterpretować potencjał semantyczny takiego etnonimu. Powieściowe kreacje onomastyczne pasożytują niejako na autorytecie historii aktualnej, wspomagając proces zadomowienia czytelnika $\mathrm{w}$ oferowanym świecie.

Fikcyjna geografia wprowadzana jest poprzez wykład o historii III Rzeszy, z którego dowiadujemy się, że „Pierścień zależnych od Rzeszy państw, od Protektoratu Bałtyckiego i Finlandii za zachodzie - Bałtyk był morzem wewnątrzniemieckim - aż po byłe komisariaty Rzeszy, a obecnie skonfederowane prowincje: Kaukaz, Zakaukazie, i Ruś (Ukrainę), którym przyznał specjalną konstytucję stanową według średniowiecznych wzorów (w nagrodę za to, że pierwsze postały przeciwko apokaliptycznej bestii bolszewizmu), oraz okręgi lenne: Chiwę, Bucharę, Kirgizję, Chakazję i Ałtaj." [Basil 1993: 31]. Basil symuluje w ten sposób głęboką perspektywę historyczną, podkreślając dynamicznie zmieniający się sposób zarządzania podległymi Rzeszy terenami. Świadczy o tym przymiotnik 'byłe' (komisariaty Rzeszy). Po raz kolejny uprawniony staje się wniosek o anachroniczności polityki III Rzeszy, reaktywowania przez nią średniowiecznych przeżytków politycznych: „Führer przyznał specjalną konstytucję stanową według średniowiecznych wzorów". Interesujące, że bezpośrednio po wprowadzeniu informacji o nadaniu średniowiecznej natury konstytucji, pojawiają się egzotyczne, zgodnie z koncepcjami orientalizmu Saida [2005, 2009] i strategią postkolonialnej lektury kontrapunktowej, etnonimy, będące nazwami okręgów lennych, a więc również wywiedzione ze stricte średniowiecznej zasady sprawowania władzy. Można z tego wysnuć następujące wnioski: opisana w Brunatnej rapsodii Światowa Ariogermańska Wspólnota Narodów jest wielkim i złożonym tworem politycznym, kierującym się archaicznymi, niedemokratycznymi zasadami rządzenia; tereny wschodniej Europy wciąż, nawet w tej dystopijnej fikcji literackiej, są opisywane jako cywilizacyjnie zapóźnione wobec Zachodu. Na zachodzie Europy występują republiki, zaś na wschodzie okręgi lenne. Tę kreację etnonimiczną należałoby w zasadzie zanalizować przy wykorzystaniu narzędzi krytyki 
postkolonialnej, orientalizmu, dyskursu kresowego oraz dyskursów postzależnościowych, by dociec przyczyn uparcie powielanego stereotypu o zapóźnieniu cywilizacyjnym terenów Europy Wschodniej, postrzeganej jako gorsza, uboższa siostra Europy Zachodniej. W zasadzie kreacja Basila jest więc pewnego rodzaju hiperbolizacją stereotypowych sądów ze świata aktualnego.

Kiedy Basil opisuje w Brunatnej rapsodii Stany Zależne Ameryki Północnej, na które w toku akcji powieści dokonuje się inwazja, wprowadza fikcyjny ojkonim Wycliff. W świecie aktualnym takie miano nosi charytatywna, misyjna instytucja pod nazwą Biblijne Stowarzyszenie Misyjne Wycliff, pracujące m.in. nad thumaczeniem Biblii i ewangelizacją ludów Afryki. Przytoczę następujące zdanie: „W Wycliffie przywódcą buntowników był murzyński ekspastor” [Basil 1993: 65]. Nazwa miasta została derywowana od eponimu, który konotuje skojarzenia $\mathrm{z}$ buntem, ponieważ John Wycliffe był XIV-wiecznym teologiem angielskim, profesorem Oksfordu, reformatorem Kościoła związanym z ruchem lollardów, zwolennikiem odnowienia Kościoła według nauki Pisma Świętego. Wycliffe został potępiony przez papieża Grzegorza XI 5 bullami i uznawany jest za prekursora reformacji. W roku 1428 biskup angielski na polecenie papieża Marcina $\mathrm{V}$ usunął kości buntownika z grobu znajdującego się na cmentarzu w Lutterworth. Zostały one zmiażdżone, spalone na popiół i wrzucone do rzeki Swift. Fakt zaś, że przywódcą buntowników w świecie Brunatnej rapsodii był murzyński ekspastor, uzyskuje dodatkowe znaczenie z racji daty wydania powieści - rok 1966. Basil czyni w ten sposób czytelną paralelę w stosunku do działalności Martina Luthera Kinga i jego walki z segregacją rasową. W ten oto sposób swoistej hiperbolizacji ulega fakt, że zwasalizowaną Ameryką rządzi Ku-Klux-Klan. Wtórny, dystopijny świat wykreowany przez Basila staje się również komentarzem do sytuacji politycznej świata aktualnego i jego problemów. Historie alternatywne są nie tylko sposobem na naprawę złej czy chorej przeszłości, ale i, będąc wypadkową poglądów społeczno-politycznych autora, stają się satyrycznym, antyutopijnym komentarzem do współczesnej rzeczywistości czasowi powstania powieści. Nic więc dziwnego, że powieści, tj. Brunatna rapsodia O. Basila czy Alteracja Kingsleya Amisa [1994, pierwodruk 1976], wpisują się w Swiftowski nurt krytyki społecznej. Co ciekawe, podobnie derywowany ojkonim w wersji Wycliff City pojawia się również we wspomnianej powyżej powieści Alteracja Amisa, a jego funkcja semantyczna jest taka sama jak w powieści Basila i również ma konotować znaczenia buntu i reformy religijnej.

W Brunatnej rapsodii warto również zwrócić uwagę na następujące ojkonimy, dowodzące podbicia przez III Rzeszę terenów w Europie Środkowo-Wschodniej: Hermannstadt, miasto w Rumunii, dawne Sibiu, Joachimstachl, dawny Jachymov w Czechosłowacji czy Fünfkirchen, dawny Peszt węgierski. Ta ostatnia kreacja jest ciekawa z racji wpisanej w nią ironii. Otóż Fünfkirchen, znaczy ' 5 kościołów’. Co ciekawe, w średniowiecznym Peszcie znajdowały się cztery kościoły i synagoga, notabene największa w ówczesnej Europie. Basil zastawia tutaj na 
nieuważnego czytelnika pułapkę. Nie znając historii nie zrozumiemy, że nazwa niesie ze sobą potężną dawkę ironii, skoro do owych pięciu świątyń zaliczono i żydowską synagogę. Dekodowanie kreacji toponomastycznych i rozpoznawanie zmienionych scenariuszy historycznych wymaga od czytelnika podstawowej wiedzy, ale od czytelnika modelowego wymaga się znacznie więcej - wiedzy pozwalającej na uczestnictwo we wspólnej grze $\mathrm{z}$ autorem, grze obliczonej na rozpoznanie i docenienie wszelkich niuansów, zmieniających tryb lektury i sposób odbioru.

Jak widać powieściowy Hitler prowadzi konsekwentną politykę toponomastyczną. Obejmuje ona również toponimię miejsc niezamieszkanych, skoro dawna cieśnina Beringa została przemianowana na cieśninę Ribbentropa [Basil 1993: 123]. Joachim von Ribbentrop był ministrem spraw zagranicznych III Rzeszy, a w latach tuż przez I wojną światową przebywał w Kanadzie. Był nawet członkiem drużyny hokejowej. Być może właśnie dlatego Basil wykreował nazwę Cieśnina Ribbentropa, bo jak wiadomo Cieśnina Beringa ze świata aktualnego łączy Morze Czukockie z Morzem Beringa, rozdzielając tym samym Eurazję od Ameryki. Być może więc nazwa ta miała upamiętnić fakt, że dzięki polityce Ribbentropa przerzucono polityczny pomost pomiędzy obydwoma kontynentami.

\section{Gothenland, czyli Krym - Vaterland Roberta Harrisa}

Równie ciekawego materiału toponomastycznego dostarcza Vaterland Roberta Harrisa. W powieści tej, podobnie jak Brunatna rapsodia pokazującej świat po zwycięskiej dla Państw Osi II wojnie światowej, również pojawia się kolegialny twór państw uzależnionych od Rzeszy Niemieckiej. Jest to Wspólnota Europejska licząca 12 państw, którą można uznać za dość przewrotną aluzję do Unii Europejskiej, a w zasadzie jej poprzedniczki Europejskiej Wspólnoty Gospodarczej. W powieści ta nazwa zresztą pada: „Dwanaście krajów Zachodu: Portugalia, Francja, Irlandia, Wielka Brytania, Belgia, Holandia, Włochy, Dania, Norwegia, Szwecja i Finlandia otoczyło wianuszkiem Rzeszę, tworząc na mocy podpisanego w Rzymie traktatu Europejską Wspólnotę Gospodarczą" [Harris 1997: 221]. Kreacje toponomastyczne stworzone w Vaterlandzie Harrisa również skłaniają do poszukiwań historycznych. Przykładowo, Krym zwany jest Gothenland. Niewattpliwie jest to przypomnienie faktu, że Goci w III w. naszej ery podbili Krym, choć długo nie zagrzali tam miejsca, wycofując się już sto lat później pod naporem Hunów [Strzelczyk 1984]. Osadnicy goccy na Krymie przetrwali jedynie w kilku wsiach w Górach Krymskich. Funkcję tego etnonimu można wytłumaczyć przy użyciu terminu „polityka historyczna”, która polega na „wzmocnieniu publicznego dyskursu o przeszłości, poprzez różne formy jego instytucjonalizacji” [Cichocki 2006: 11], czy słowami innego ze zwolenników tego typu działania, D. Gawina, ,instrumentów afirmacji zbiorowej tożsamości (w tym przede wszystkim wspólnej przeszłości” [Gawin 2006]. Mimo iż termin 
polityka historyczna w odniesieniu do powieści Harrisa jest oczywistym anachronizmem, to jednak doskonale wpisuje się w działania propagandowe III Rzeszy, inicjowane m.in. przez Josepha Paula Goebbelsa, ministra propagandy i oświecenia publicznego, polegające m.in. na odnajdywaniu rzekomo rdzennie germańskich elementów na terenach podbitych, powracających w ten sposób do Rzeszy. Historia świata aktualnego potwierdza oczywiście takie działania propagandowe III Rzeszy. Ciąg przemianowanych nazw państw w Vaterlandzie wygląda następująco: Luksemburg stał się Mossenlandem (Mozela to rzeka graniczna pomiędzy Niemcami a Luksemburgiem; tak ukuta nazwa znosi element rozdzielający, a wskazuje na inkorporację Luksemburga w obręb Rzeszy); Alzacja i Lotaryngia są Westmarkiem, Austria Ostmarkiem, Czechosłowacja: Protektoratem Czech i Moraw (tak było w świecie aktualnym), Polska, Litwa, Łotwa i Estonia zostały wykreślone z mapy. Co ciekawe, nazwy Katowice i Kraków zostały w powieści zachowane [Harris 1997: 69], co jest efektem błędnego, hiperpoprawnego, nierespektującego logiki powieści thumaczenia dokonanego przez A. Szulca. W wersji oryginalnej, angielskiej padają nazwy niemieckie Kattowitz i Krakau [Harris 1992: 52].

Równie dużo o historii i jej alternatywizacji mówi nazewnictwo ulic Berlina, wprowadzone w powieści za pomocą użycia chwytu ,przewodnik oprowadza wycieczkę" oraz chrematonimia. Poznajemy historię powstania Łuku Zwycięstwa (budowa rozpoczęta w 1946, ukończona w 1950 w Dniu Odrodzenia Narodowego), który jest 49 razy większy od Łuku Tryumfalnego w Paryżu (hiperbolizacja tzw. architektury monumentalnej Rzeszy). Spod łuku wjeżdża się w Aleję Zwycięstwa, której zakończeniem jest Adolf Hitler Platz, a jak doskonale wiadomo we wszystkich większych miastach podbitych przez Rzeszę tak nazywano rynki, np. krakowski. Z dworca Gotenlandzkiego pociagi wyruszają do Gothenland, czyli Krymu (ze świata aktualnego), a konkretnie do Theodorichshafen (dawny Sewastopol), Genneralkomissariatu Taurydy i jego stolicy Melitopolu (Tauryda to antyczna grecka nazwa Krymu). Te ostatnie dwie nazwy są zaczerpnięte z historii rzeczywistej, bo utworzony po zwycięstwie Niemiec nad Związkiem Radzieckim w 1941 r. Okręg Generalny Krym zwany był właśnie Tauryda, choć jego stolicą nie był Melitopol. Toponomastyka wykreowana przez Harrisa bardziej niż ta z Brunatnej rapsodii Basila bazuje na tej znanej z rzeczywistej historii. Wynika to chyba $\mathrm{z}$ faktu, że dla powieści Vaterland najistotniejszym porządkiem genologicznym jest powieść kryminalna, górująca wyraźnie nad potrzebami historii alternatywnej, podczas gdy w przypadku Brunatnej rapsodii mieliśmy do czynienia z dystopijna, czy wręcz kakotopijną historią alternatywną, która miała unaocznić apokaliptyczny wręcz wymiar szaleństwa III Rzeszy. Prymarnym celem Harrisa było ułatwienie procesu immersji, bardziej potwierdzanie niż przekraczanie czytelniczego horyzontu oczekiwań. Basil w Brunatnej rapsodii wywołuje przede wszystkim efekt obcości, groteski -, ,groteska, to świat który stał się obcy” [Kayser 1979: 276] - potęgującego poczucie zagrożenia i lęku przed tym, że właśnie tak mógł wyglądać nasz świat. 


\section{Hussville i Cranmeria - ojkonimy i aluzje osobowe w Alteracji Kingsleya Amisa}

Równie mroczny świat jak w Brunatnej rapsodii Basila, kreuje Kingsley Amis w Alteracji (1976 r.). Świat tej powieści jest efektem tego, że w Anglii nie dokonała się reformacja. W alternatywnym XX w. Wielka Brytania światopoglądowo przypomina mroczne średniowiecze, bo wciąż poddana jest Kościołowi i Watykanowi. Praktykuje się czary, trwają polowania na czarownice, a elektryczność i nauka są zakazane. Świat wykreowany przez Amisa jest ewidentnie dystopijny, a pisarz świadomie wpisał się w nurt komiczno-katastroficznych antyutopii brytyjskich, sygnowanych nazwiskami, tj. Jonathan Swift czy George Orwell. Autor Alteracji nie tyle satyrycznie odnosi się do zastanej rzeczywistości, kontestując ją, ile stara się uzmysłowić wszelkim malkontentom, że rzeczywistość, w której żyją nie jest najgorsza z możliwych. P. Znaniecki w posłowiu do powieści nazywa wręcz Alteracje „powieścią rozliczeniową" [Znaniecki 1994: 196]. Krytycyzm wobec katolicyzmu przybiera w tej powieści wyjątkowe oblicze. Amis bez żadnych hamulców krytykuje kontynentalną, zaściankową katolicką mentalność. Akcja zorganizowana jest wokół zabiegu kastracji (tytułowa alteracja), jakiemu na życzenie Kościoła ma zostać poddany Hubert Anvil, obdarzony anielskim głosem śpiewak. Siła Kościoła katolickiego w świecie przedstawionym jest konsekwencją powrotu Marcina Lutra na łono Kościoła katolickiego. Twórca reformacji ze świata aktualnego w Alteracji został papieżem, do tego antysemitą i przybrał imię Germanian I. W efekcie Thomas More (czyli Thomas Morus autor Utopii) nie musiał składać za wiarę ofiary z życia i jako Hadrian VII był następcą Marcina Lutra na Stolicy Piotrowej. More nie został jednak świętym Kościoła katolickiego. Katolicyzm przybrał formę totalitarną, a zasiadający na Stolicy Piotrowej papież jest ludobójca. Postać ta wzorowana jest na brytyjskim premierze $\mathrm{H}$. Wilsonie, przywódcy partii laburzystów, sprawującym swą funkcję w latach 60 . i 70. XX w. Satyryczna aluzja osobowa mieści się w dokonaniach brytyjskiej satyry osobistej, rozkwitającej w XVIII w. pod piórami Swifta czy Pope a [Znaniecki 1994: 196]. Jest to wyraźny dowód, że historie alternatywne mogą stanowić również ironiczny kontr-dyskurs rzeczywistości i być komentarzem do wydarzeń współczesnych pisarzowi. W Alteracji Watykan wciąż posługuje się inkwizycją, a jej metody po doświadczeniach II wojny światowej (co ciekawe konflikt również przetoczył się przez świat wykreowany przez Amisa) nie odbiegają od metod gestapowskich czy praktykowanych przez NKWD. Taką interpretację ułatwiają aluzje osobowe występujące w powieści. Dwaj hierarchowie Inkwizycji, Monsignore Henricus i Monsignore Laurentis, to nie kto inny jak Heinrich Himmler i Ławrientij Beria.

Mimo iż w świecie powieściowym Alteracji w Anglii nie dokonała się reformacja, to jednak, za sprawą wystapienia Lutra, narodził się protestantyzm. 
Ponieważ jednak Luter wyrzekł się „błędnej ścieżki”, Europa pozostała katolicka. Nauka Lutra dotarła jednak za ocean i tam, w Republice Nowej Anglii (USA świata aktualnego) rozwijała się bez większych przeszkód. W Republice Nowej Anglii znajdziemy więc ojkonimy będące eponimami patronimicznymi, tj. Hussville, Cranmeria czy Wycliffe City. Każda z tych nazw odwołuje się do postaci buntowników (Jan Hus, Jan Tomasz Cranmer i John Wycliffe) wzywających do odnowy Kościoła katolickiego. Najmniej rozpoznawalny z tej trójki jest w Polsce Tomasz Cranmer (1489-1556), arcybiskup Canterbury za czasów Henryka VIII i Elżbiety I. Był on przywódcą reformy anglikańskiej i został stracony na rozkaz katolickiej królowej Marii I Tudor, tzw. Bloody Mary. Przytoczone powyżej ojkonimy mają ułatwić rozpoznanie Republiki Nowej Anglii jako kraju konsekwentnie protestanckiego. Od nazwy wydarzenia historycznego, a nie eponimu, została zaś utworzona nazwa Nowa Wittenberga. I ta nazwa pozostaje w polu semantycznym protestantyzmu, bo jak wiadomo właśnie na drzwiach kościoła w Wittenberdze Marcin Lutter przybił w 1517 roku słynnych 95 tez, rozpoczynając tym samym erę reformacji. W świecie aktualnym miasto to zostało nazwane Lutterstadt Wittenberg, niewatpliwie w celu komemoracji Marcina Lutra. Co ciekawe, w Alteracji, Nowy Jork zwany jest wciąż Nowym Amsterdamem, co nie oznacza jednak, iż nie należy on w powieści do terenów zarządzanych przez Republikę Nowej Anglii. Ten anachroniczny ojkonim ma, jak sądzę, wspomagać proces budowy alternatywizowanego dystansu historycznego oraz symulować głębię czasową i historyczną świata przedstawionego.

\section{Calisia czyli ziemie polskie prowincją rzymską - Quietus Jacka Inglota}

Po zupełnie inny, bo łaciński i antyczny, modus kreacji toponomastyki sięgnął Jacek Inglot w powieści Quietus [Inglot 2011]. Powód takiej kreacji tłumaczy już podtytuł powieści Powieść z dziejów rzymskich $i$ wenedyjskich. Wenedowie to lud zamieszkujący w I-IV w. n.e. ziemie nad Bałtykiem, utożsamiany najczęściej ze Słowianami zachodnimi, a przez Słowackiego w Lilli Wenedzie uznany za przedhistorycznych Polaków. Powieść Inglota rozgrywa się jednak mniej więcej w VII wieku n.e., a Wenedia od czasów księcia Dagona (urealniony mit historyczny, por. akt Dagome iudex) jest prowincją rzymską ze stolicą w Calisii. Pisarz wybrał konsekwentnie łacińską pisownię, uwiarygodniającą kreację świata przedstawionego. Słowianie zwani są Sclavinami, Mazowsze Masovią, Śląsk Bohemią, Paryż zaś Parisią. W tym miejscu konsekwencja toponomastyczna Inglota jednak zawodzi, bo jak wiadomo, w czasach rzymskich miasto to zwane było Lutetia Parisiorum. Nazwa Parisia ma być chyba ułatwieniem percepcyjnym dla czytelnika. Warto zatem podkreślić, że oryginalną łacińską nazwę Paryża wykorzystał J. Dukaj w Innych pieśniach [Dukaj 2003] i to bez 
uszczerbku dla rozpoznawalności, z niewątpliwym zaś zyskiem dla wiarygodności. Toponomastyka powieści Quietus jest efektem tego, że Imperium Romanum przetrwało najazdy ludów północy, a cesarz Julian Apostata wytępił chrześcijaństwo. To właśnie z pomocą m.in. Wenedów wyciął w pień pół Azji Mniejszej, a zakazana sekta chrześcijańska zniknęła z kart historii. Trwa jednak w ukryciu, zaciekle zwalczana przez władzę. Nieco inne chrześcijaństwo istnieje jednak na Wschodzie. W świecie wykreowanym przez Inglota, „herezja afrykańska”, czyli znana ze świata aktualnego schizma Donata (biskup Kartaginy, ok. 313-355 n.e.), żądająca od wyznawców dyscypliny, bezgrzeszności i totalnego posłuszeństwa (donatyzm to „kościół męczenników”, kościół ludzi doskonałych) dotarła do Nipu, do Japonii, i tam, w połączeniu z shintoizmem, stała się religią państwową. Była to jednak religia miecza, a nie miłości i miłosierdzia. Tamtejsze chrześcijaństwo stanowiło więc mroczny rewers nauk Chrystusa.

\section{Korony kratistosów i Soplicowo - toponimia i eponimia w Innych pieśniach i Lodzie Jacka Dukaja}

Wspomniany już Jacek Dukaj w Innych pieśniach, wykreował konsekwentny językowo świat, w którym prymat polityczny należy do świata helleńskiego a nie rzymskiego. Jest to efektem faktu, że Aleksander Wielki nie zginął w wieku 33 lat i założył największe mocarstwo na świecie. Potęga mocarstwa jest wspomagana przez specyficzną fizykę funkcjonującą w opisanym przez Dukaja świecie - fizykę czterech żywiołów Empedoklesa z Akragas i hylemorfizm Arystotelesa (dualizm materii i formy). Akcja powieści rozgrywa się XII w. ery aleksandryjskiej (czyli ab urbe condita, od 332 r. p.n.e). Ziemie polskie zwą się Vistulia, stolicą jest Gniezno. Inne wymienione polskie lokacje to Bresla, niewatpliwie dzisiejszy Wrocław. Centrum świata Alexandria znajduje się w koronie Hypatii. Hypatia to dziedziczne miano władczyni miasta, derywowane od słynnej filozofki, Hypatii z Aleksandrii 355-415 n.e. W Innych pieśniach nie znajdziemy typowych etnonimów, oznaczających nazwy państw. W powieści bowiem ponad tworem politycznym, państwem, znajduje się tzw. korona kratistosów, siedmiu wielkich strategosów i poniekąd magów, którzy mają tak silną formę, że nadają ją całemu terenowi objętemu ich wpływem. I tak, ludzie z korony Hypatii mają złocistą cerę, a w obecności kratisotsa fizycznie maleją. Stało się to udziałem głównego bohatera powieści Hieronima Berbeleka, który rzuciwszy wyzwanie kratistosowi Moskwy, Maksymowi Rogowi, przegrał, na skutek czego fizycznie skurczył się. Korona ciąży więc nad dużymi terenami, znosząc w zasadzie podziały państwowe, bo mieszkańcy danej korony upodabniają się do siebie. Etnonimy przybierają więc $\mathrm{w}$ tej powieści postać patronimików.

Na uwagę zasługuje kreacja tzw. Krzywych Krain, Skolidoi, znajdujących się w głębokiej Afryce terenów, gdzie morfowanie zachodzi niezwykle dynamicznie, 
zmieniając formę ludzi i zwierząt wkraczających w te tereny. Tak powstają mutacje, kakomorfy. Oszczędna, choć nastawiona bardziej na strategię obcości niż ułatwienia percepcyjnego, toponomastyka Dukaja, zasługuje na zainteresowanie poprzez fakt jej konsekwencji i podporządkowania warstwy onomastycznej wymyślonemu na potrzeby powieści językowi (inny zapis znanych słów, np. kaffa, zamiast kawa, terminologia polityczna i wtręty z języka greckiego) i konstrukcyjnej utworu. Dukaj świadomie unika zbyt łatwych rozwiązań, bazujących na zbyt dużej przyległości do świata aktualnego. Jego celem jest bowiem wykreowanie w pełni wiarygodnego, choć dość oddalonego od przyzwyczajeń percepcyjnych czytelników, oryginalnego świata, maksymalnie odległego od świata aktualnego. Dukaj zmusza swych czytelników do znacznego wykreślenia poza ich standardowy horyzont oczekiwań.

Podobną strategię odnajdziemy w Lodzie [Dukaj 2007]. Kształt świata i historii jest efektem upadku meteorytu tunguskiego, który zamraża historię w jej kształcie z roku 1908. W 1924 r. Polska wciąż nie istnieje i leży w Kraju Przywiślańskim, w Cesarstwie Rosyjskim. W Warszawie stacjonują wojska carskie i administracja rosyjska. Akcja powieści rozpoczyna się w Warszawie, znanej z okresu fin de sièclu. Ministerium Zimy (powiedzmy, że jest to ministerstwo polityki i spraw wewnętrznych) znajduje się w dawnym Pałacu Biskupów Krakowskich przy ul. Miodowej 5, róg Senatorskiej. Powszechnie znana topografia jest jednak zupełnie inna, bo nad Warszawą panują lute, anioły Lodu, zmieniające wygląd miasta nie do poznania. Nazwy miast i ulic są czytelne i swojskie, to świat zmienił się radykalnie, stał się groteskowy, przerażający i obcy [Kayser 1979: 276]. Pozorna zbieżność toponomastyczna potęguje więc jedynie ów efekt obcości. Na uwagę zasługuje nazwa gniazda aniołów lodu. Zwie się ono Soplicowo. Dukaj zamienił fikcyjna, wywiedzioną z eposu narodowego Mickiewicza nazwę własną na nazwę pospolita, zmieniając tym samym Arkadię - symbol i ostoję polskości i szlacheckiej wolności - w Horrendum - symbol zniewolenia i braku możliwości działania. Ta obrazoburcza dla polskich mitów narodowych nazwa jest efektem dyskusji Dukaja z mitami narodowymi, m.in. dotyczącymi państwowości polskiej. Dukaj w Lodzie kwestionuje tezę, że Polska jako twór polityczny była bytem koniecznym i najlepszym z możliwych, a jej odrodzenie było koniecznością historyczną [por. Lemann 2012a, 2012d]. Dukaj po raz kolejny wykorzystuje toponomastykę w polemicznych celach, nazywając dworzec w Irkucku nazwiskiem Murawiowa. Nazwa ma oczywiście upamiętniać generał-gubernatora wschodniej Syberii, Nikołaja Murawiowa-Amurskiego, który w roku 1857 zainicjował powstanie kolei transsyberyjskiej. Dla Polaków jednak nazwisko Murawiow kojarzy się jednak z Michaiłem Murawiowem wileńskim, tzw. Wieszatielem, generał-gubernatorem, który w czasie powstania styczniowego i tuż po jego pacyfikacji wsławił się szczególnym okrucieństwem wobec Polaków. Notabene Nikołaj Murawiow-Amurski był kuzynem Wieszatiela. Na ten trop interpretacyjny naprowadza również ojkonim Irkuck. Miasto jak wiadomo było główną stacją przesiadkową dla skazańców 
polskich idących na Sybir. Chrematonimia jest więc zadaną czytelnikowi lekcją podwyższonej czujności wobec historii i czytanego tekstu. Zbyt łatwe bazowanie na doświadczeniach czytelniczych, przekładanie świata aktualnego na powieściowy, prowadzi do błędnych interpretacji. Notabene, Irkuck w Lodzie okazuje się miastem, w którym Polacy sobie doskonale gospodarczo radzą, przemyśliwując nawet nad stworzeniem Zjednoczonych Stanów Syberii, co choć jest prawdą historyczną, godzi w skrzętnie pielęgnowany mit polskiego męczeństwa na Syberii [por. Kopeć 2013, 2014].

\section{Podsumowanie}

Wszystkie omówione przeze mnie powieści wykorzystują makro- i mikrotoponimię jako element kształtujący alternatywne oblicze historii. Nic więc dziwnego, że analizując kreacje toponimiczne należy posługiwać się bardziej wiedzą historyczną niż procedurami stricte lingwistycznymi. Analiza omówionych przykładów pozwala zauważyć, że autorzy największą wagę przywiązują do kreacji etnonimów oraz ojkonimów, jako mających największy potencjał alternatywno-historiotwórczy. Przeważają toponimy eponimiczne, których właściwe zdekodowanie pozwala na pogłębienie perspektywy historycznej utworu i staje się czytelnym elementem gry $\mathrm{w}$ zmienioną historię. Oczywiście jako warunek porozumienia potrzebna jest wspólna przestrzeń wiedzy i kultury pomiędzy autorem i czytelnikiem, bo przykładowo nazwa Soplicowo czy dworzec Murawiowa prawdopodobnie nie zostaną prawidłowo zdekodowane przez czytelników obcojęzycznych, podobnie jak polscy odbiorcy Alteracji mogą mieć problem z prawidłową interpretacją nazw Wycliff City czy Cranmeria. Dowodzi to, jak sądzę, potrzeby pogłębionej kulturowo i historycznie wielopoziomowej analizy onomastyki literackiej, m.in. właśnie w zakresie toponimii.

\section{Bibliografia}

Amis Kingsley, 1994, Alteracja, tłum. Przemysław Znaniecki, Poznań.

Basil Otto, 1993, Brunatna rapsodia, thum. Ryszard Wojnakowski, Warszawa.

Cichocki Marek, 2006, Polityka historyczna za i przeciw, „Mówią Wieki” 8, 11.

Demandt Aleksander, 1999, Historia niebyła. Co by byto, gdyby...?, thum. Maria Skalska, Warszawa.

Dick Philip Kindred,1981, Człowiek z wysokiego zamku, tłum. Lech Jęczmyk Warszawa.

Dukaj Jacek, 2003, Inne pieśni, Kraków.

Dukaj Jacek, 2007, Lód, Kraków.

Ferguson Nial (ed.), 1997, Virtual History: Alternatives and Counterfactauls, New York.

Foucault Michel, 1993, Nadzorować i karać. Narodziny więzienia, thum. Tadeusz Komendant, Warszawa. 
Foucault Michel, 2002, Porzqdek dyskursu. Wykład inauguracyjny wygłoszony w College de France 2 grudnia 1970, tłum. Michał Kozłowski, Gdańsk.

Franczak Jerzy, 2012, Literatura i władza, [w:] Teresa Walas, Ryszard Nycz (red.), Kulturowa teoria literatury 2. Poetyki, problematyki, interpretacje, Kraków, 439-492.

Gallagher Catherine, Greenblatt Stephen, 2000, Practicing New Historicism, Chicago - London.

Gawin Dariusz, 2006, Wspólnota przeszłości, „Rzeczpospolita” z dn. 7 października. Cyt. za: http:// www.teologiapolityczna.pl/gawin_06_10_wspolnota_przeszlosci (dostęp: 30.12.2011).

Greenblatt Stephen, 2006, Poetyka kulturowa. Pisma wybrane, wstęp Krystyna Kujawińska-Courtney (.), Kraków.

Harris Robert 1992, Fatherland, e-pub version.

Harris Robert, 1997, Vaterland, thum. Andrzej Szulc, Warszawa.

Hellekson Karen, 2001, The Alternate History. Refiguring Historical Time, Kent, Ohio \& London.

Inglot Jacek, 2011, Quietus, Warszawa.

Iser Wolfgang, 2006, Apelacyjna struktura tekstów, tłum. Włodzimierz Bialik, [w:] Anna Burzyńska, Michał Paweł Markowski (red.), Teorie literatury XX wieku. Antologia, Kraków, 71-93.

Jameson Frederick, 1981, The Political Uncouncious. Narrative as a Socially Symbolic Act, London. Kayser Wolfgang, 1979, Próba określenia istoty groteskowości, „Pamiętnik Literacki” 4.

Kopeć Zbigniew, 2013, Polski dyskurs syberyjski, [w:] Hanna Gosk, Ewa Kraskowska (red.), (P)O zaborach, (P)O wojnie, (P)O PRL. Polski dyskurs postzależnościowy dawniej i dziś, Kraków, 151-167.

Kopeć Zbigniew, 2014, Syberia przepisana, „Zagadnienia Rodzajów Literackich”, t. 57, z. 2 (114), 139-148.

Lemann Natalia, 2002, Trzynaście kotów, trzynaście poczatków, [w:] Gerhard Giesemann, Tatiana Stepnowska (red.), Literaturwissenschaftliche und linguistische Forschungaspekte der phantastischen Literatur, Frankfurt am Main-Berlin-Bern-Bruxelles-New York-Oxford-Wien, 139-168.

Lemann Natalia, 2011a, Czy można uchronić się od przeszłości? - historie alternatywne i uchronie jako literackie aporie wiedzy historycznej i polityki, „Zagadnienia Rodzajów Literackich” t. 54, z. 2, 339-356.

Lemann Natalia 2011b, PODobna historia, czyli rzecz o historii alternatywnej i jej miejscu we wspótczesnej historiografii i literaturoznawstwie, [w:] Zdzisław Wąsik, Marek Oziewicz, Justyna Deszcz-Tryhubczak (red.), Exploring the Benefits of the Alternate History Genre I $W$ poszukiwaniu pożyteczności gatunku historii alternatywnych, „Philologica Wratislaviensia: Acta et Studia", vol. 5, 21-38.

Lemann Natalia, 2012a, AntiPODes of History? „Muza dalekich podróży” by Teodor Parnicki and "Lód” by Jacek Dukaj as Two Diffrent Models od Approaching Alternative History, [in:] Dorota Guttfeld, Monika Linke, Agnieszka Sowińska (ed.), (Re)Visions of History in Language and Fiction, Cambridge, 301-319.

Lemann Natalia, 2012b, Czy historia może być skandalem? Rzecz o historiach alternatywnych i ich sporach z przeszłościq/teraźniejszościq, [w:] Bożena Płonka-Syroka, Marian Ursel (red.), Skandal w kulturze, Seria: Tabu. Trend. Transgresja, t. 1, Warszawa, 123-138.

Lemann Natalia, 2012c, Historie alternatywne, [w:] Grzegorz Gazda (red.), Stownik gatunków i rodzajów literackich, Warszawa, 380-388.

Lemann Natalia, 2012d, PODobni NiePODobni. „Muza dalekich podróży” Teodora Parnickiego $i$ „Lód” Jacka Dukaja jako przykład dwóch sposobów relatywizacji historii, „Porównania” 10, vol. X, 173-188.

Ranciére Jacques, 2008, Na brzegach politycznego, tłum. Jan Sowa, Kraków.

Rosenfeld Gavriel David, 2005, The World Hitler Never Made, Cambridge.

Ryan Marie-Laure, 2001, Narrative as Virtual Reality, Baltimore.

Said Edward, 2005, Orientalizm, tłum. Monika Wyrwas-Wiśniewska, Poznań. 
Said Edward, 2009, Kultura i imperializm, tłum. Monika Wyrwas-Wiśniewska, Kraków.

Stoff Andrzej, 1994, Sposoby stanowienia rzeczywistości niewerystycznej w poczatkowych partiach utwórów science-fiction, [w:] Anna Martuszewska (red.), Fantastyka, fantastyczność, fantazmaty, Gdańsk, 37-55.

Strzelczyk Jerzy, 1984, Goci: rzeczywistość i legenda, Warszawa.

Veeser Aram (ed.), 1994, The New Historicism Reader, New York.

Znaniecki Przemysław, 1994, Postowie, [w:] Kingsley William Amis, Alteracja, Poznań, 195-198.

Natalia Lemann

\section{AntiPODian places - toponomastics in alternative history}

\section{(Summary)}

The aim of the alternative histories, speculative, literary genre, is to show and describe the different scenarios of historical events. Those events, although possible, does not became truth. This genre persuades the reader for intertextual lecture in relation to history known from the actual world. Changing the toponomastics in created, secondary universe is one of the most interesting methods of alternate the history. Writers builds the alternate toponomastics, e.g. ethnonims, ojkonims, chrematonims, eponims for the purpose of authenticate the changing history scenario. It seems interesting to analyze toponomastics in following scopes: using of historical knowledge for decoding the semantic potential of such historical and toponymy mdifications; alternate the historical discourse via toponymy; cultural background of changed toponomastics; reception issues (sender and recipient competences). The tension between recognisability and strangeness of toponymy is marked by the title, author's pun 'AntiPODian places', utilizing the primal for the alternative history genre hallmark, point of divergence. This term means the crucial moment when the historical events separated from the path known from the actual world. The raised problems are examine with the scientific procedure of epistemology of history, cultural anthropology, literary anthropology and cultural studies. The material under investigation derived from following novels: Vaterland by Robert Harris, Wenn das der Führer wüsste by Otto Basil, The Alteration by Kingsley Amis, Quietus. Powieść z dziejów rzymskich $i$ wenedyjskich by Jacek Inglot and Inne Pieśni and Lód by Jacek Dukaj.

Slowa kluczowe: toponomastyka, literatura, historia alternatywna.

Keywords: toponomastic, literature, alternative history. 